A Papi reports grants, personal fees, and/or reimbursement of travel expenses from Astrazeneca, Chiesi, Boehringer Ingelheim, GlaxoSmithKline, Menarini, Merck Sharp \& Dohme, Mundipharma, Novartis, Teva, Sanofi, Zambon.

\section{P275 COMPARING CLINICALLY RELEVANT IMPROVEMENT WITH UMECLIDINIUM/VILANTEROL AND TIOTROPIUM/ OLODATEROL IN SYMPTOMATIC COPD: A RANDOMISED NON-INFERIORITY CROSSOVER TRIAL}

\subsection{6/thoraxjnl-2017-210983.473}

This study (204990 [NCT02799784]) was funded by GSK.

C Compton, AR Sousa, D Lipson, I Naya and S Patel are employees of GSK and hold stocks/shares in GSK.

$\mathrm{L}$ Tombs is a contingent worker on assignment at GSK.

$\mathrm{G}$ Feldman has no disclosures to declare.

B Alcázar Navarrete declares the following conflicts of interest: personal fees and non-financial support from Boehringer Ingelheim, Chiesi and GSK; grants, personal fees and non-financial support from Novartis AG and Laboratorios Menarini; and personal fees from Astra-Zeneca and Gebro. In addition, Dr. Alcázar Navarrete has a patent (P201730724) pending.

\section{P276 CARDIOVASCULAR SAFETY OF EXTRAFINE SINGLE INHALER TRIPLE COMBINATION OF BECLOMETASONE DIPROPIONATE, FORMOTEROL FUMARATE, AND GLYCOPYRRONIUM BROMIDE IN COPD: RESULTS OF SAFETY ANALYSIS FROM THE TRILOGY AND TRINITY STUDIES}

10.1136/thoraxjnl-2017-210983.474

The research was funded by Chiesi Farmaceutici S.p.A.

M Scuri, I Montagna, C Francisco, G Cohuet, S Vezzoli, A Muraro and S Petruzzelli are employees of Chiesi Farmaceutici S.p.A.

$\mathrm{J}$ Vestbo has received honoraria from AstraZeneca, Boehringer-Ingelheim, Chiesi, GSK and Novartis.

D Singh has received honoraria from Apellis, AstraZeneca, Boehringer Ingelheim, Chiesi, Cipla, Genentech, GlaxoSmithKline, Glenmark, Johnson and Johnson, Menarini, Mundipharma, Novartis, Peptinnovate, Pfizer, Pulmatrix, Skypharma, Teva, Therevance and Verona.

M Corradi has received honoraria from Chiesi.

A Papi reports grants, personal fees, and/or reimbursement of travel expenses from Astrazeneca, Chiesi, Boehringer Ingelheim, GlaxoSmithKline, Menarini, Merck Sharp \& Dohme, Mundipharma, Novartis, Teva, Sanofi, Zambon. NOT SUBSEQUENT FVC DECLINE IN PATIENTS WITH IPF

10.1136/thoraxjnl-2017-210983.475

L Richeldi reports grants and personal fees from Boehringer Ingelheim, during the conduct of the study; grants and personal fees from InterMune, personal fees from Medimmune, personal fees from Biogen-Idec, personal fees from SanofiAventis, personal fees from Roche, personal fees from Takeda, personal fees from ImmuneWorks, personal fees from Shionogi, outside the submitted work.

$\mathrm{M}$ Kolb reports grants and personal fees from Boehringer Ingelheim, during the conduct of the study; grants and personal fees from Roche, grants and personal fees from Boehringer Ingelheim, personal fees from GSK, personal fees from Gilead, grants from Actelion, grants from Respivert, personal fees from Astra Zeneca, personal fees from Prometic, personal fees from Genoa, grants from Canadian Institute for Health Research, grants from Canadian Pulmonary Fibrosis Foundation, outside the submitted work.

A Azuma reports personal fees from Boehringer Ingelheim, outside the submitted work.

W Stansen, M Quaresma and S Stowasser are employees of Boehringer Ingelheim.

B Crestani reports personal fees and non-financial support from astra-zeneca, grants, personal fees and non-financial support from boehringer ingelheim, non-financial support from cardif, non-financial support from lvl, personal fees and non-financial support from apelis, grants from medImmune, personal fees and non-financial support from sanofi, outside the submitted work.

\section{M30 EFFECT OF DOSE REDUCTIONS AND/OR INTERRUPTIONS ON THE EFFICACY OF NINTEDANIB IN PATIENTS WITH IDIOPATHIC PULMONARY FIBROSIS (IPF): SUBGROUP ANALYSIS OF THE INPULSIS TRIALS}

\subsection{6/thoraxjnl-2017-210983.476}

$\mathrm{T}$ Maher reports that he is an investigator in an ongoing phase $2 b$ study from Gilead, grants and personal fees from GSK, grants from Novartis, personal fees from Boehringer Ingelheim, personal fees from GSK, personal fees from InterMune, personal fees from Lanthio, non-financial support from Takeda, personal fees from Sanofi Aventis, grants and nonfinancial support from UCB, personal fees from Astra Zeneca, personal fees from Roche, personal fees from Bayer, personal fees from Biogen Idec, personal fees from Cipla, personal fees from DOSA, personal fees from ProMetic, personal fees from Galapagos, outside the submitted work.

Y Inoue personal fees from Boehringer Ingelheim, personal fees from Shionogi \& Co., Ltd, personal fees from Asahi Kasei, personal fees from Novartis, personal fees from Nobel Pharma, outside the submitted work.

$\mathrm{AH}$ Case reports personal fees from Boehringer Ingelheim, outside the submitted work. 